\title{
Effects of mussel and host fish density on reproduction potential of a threatened unionoid mussel: prioritization of conservation locations in management trade-offs
}

\author{
Lea D. Schneider ${ }^{1}$ (D) P. Anders Nilsson ${ }^{1,2} \cdot$ Johan Höjesjö $^{3} \cdot$ E. Martin Österling ${ }^{1}$
}

Received: 17 January 2018 / Revised: 1 October 2018 / Accepted: 19 October 2018 /

Published online: 31 October 2018

(C) The Author(s) 2018

\begin{abstract}
Management decisions in conservation of threatened species require trading off social needs against biodiversity values, including the prioritization of conservation locations, i.e. where conservation efforts should take place. To improve conservation decisions for the thick-shelled river mussel, Unio crassus, a highly threatened temporary parasite on fish, we performed a field study on how mussel and host fish density (European bullhead, Cottus gobio, and common minnow, Phoxinus phoxinus) affect reproduction potential of the mussel at different sites along a river. We assumed that the proportions of gravid mussels would be higher at high mussel density, and result in enhanced glochidia (mussel larvae) encapsulation rates on fish. We also expected the highest 'glochidia density' - a proxy for the potential number of recruits per stream area, assessed by multiplying glochidia encapsulation rates on fish by fish density, to occur at high mussel density sites. Such river sites, producing many offspring and conveying important conservation values, may thus be prioritized. However, contrary to our assumptions, higher glochidia density and higher proportions of gravid mussels occurred at lower density mussel sites. We also found that $P$. phoxinus had higher glochidia encapsulation rates than $C$. gobio, possibly related to species-specific behavioural and life-history traits. Even so, glochidia density was similar for both fish species, reflecting comparable ecological functions in hosts. The results of this study suggest that mussel and host fish densities should be considered along with glochidia density in conservation prioritization and management trade-offs.
\end{abstract}

Keywords Host fish availability · Host-parasite system · Unionoida · Endangered species · Unio crassus

Communicated by Robert Cowie.

This article belongs to the Topical Collection: Coastal and marine biodiversity.

Lea D. Schneider

lea.d.schneider@gmail.com

Extended author information available on the last page of the article 


\section{Introduction}

The ongoing decline of biodiversity is a major global concern in need of conservation action to prevent further species extinctions (Cardinale et al. 2012). Despite increasing knowledge of anthropogenic impacts on ecosystems, saving all endangered species and populations seems unrealistic (Mace 2010; Myers et al. 2000). Management trade-offs and prioritization, in light of, for example, limited resources, human interests, ecosystem services and geographic constraints, are inevitable, and selection of priority locations is required for conservation efforts (Kapos et al. 2010; Leader-Williams et al. 2010).

Prioritization of conservation units such as biodiversity hotspots, keystone species or habitats and populations with high conservation value should be favourable (Geist 2011; Myers et al. 2000). However, assessment of conservation value is complex and should consider both intrinsic biodiversity values (Soulé 1985) and integrative ecosystem service functions (Luck et al. 2003; Ormerod 2014; Rodriguez et al. 2006). Conservation management should moreover understand the effects of habitat destruction and fragmentation, as these may affect effective population size and thereby lead to complicating factors such as Allee effects and inbreeding depression (Berg et al. 2008; Simberloff and Abele 1982). Concepts such as minimum viable population size are thus important when prioritizing management strategies for low-density populations of highly threatened keystone species (Nunney and Campbell 1993).

Many large freshwater mussels (Bivalvia: Unionoida) are highly threatened keystone species with high conservation value (Collier et al. 2016; Dudgeon et al. 2006; Strayer et al. 2004). Unionoids are benthic filter feeders, providing important freshwater ecosystem functions and services such as water purification, nutrient cycling and retention, biodeposition, sediment mixing and stabilization (Howard and Cuffey 2006; Strayer et al. 1994; Vaughn 2010, 2018; Vaughn and Hakenkamp 2001), with positive effects on freshwater biodiversity (Aldridge et al. 2007; Limm and Power 2011; Vaughn et al. 2008). Unionoids have a complex life cycle, including a parasitic larval life stage in most species (Bauer 2001a). In the families Unionidae, Margaritiferidae and Hyriidae, mussel larvae (glochidia) temporarily attach to fish (weeks-months) and then transform to free-living juveniles that bury in stream or lake sediments to eventually develop into adults (Barnhart et al. 2008; Bauer 2001b). Habitat quality and host availability are critical for life-cycle completion, making unionoids vulnerable to, for example, water pollution, invasive species and habitat degradation (Österling et al. 2010; Strayer et al. 2004; Vaughn and Taylor 2000). Strong declines in unionoid populations have occurred since the industrial revolution, and they are one of the most imperiled taxa globally (Cuttelod et al. 2011; IUCN 2018; Lopes-Lima et al. 2017; Lydeard et al. 2004; Tedesco et al. 2014). About $45 \%$ of the 679 currently recognized unionoid species worldwide are classified as near threatened, threatened or extinct, including 25 (2.5\%) extinct or probably extinct species (Lopes-Lima et al. 2018).

The preservation of the ecosystem functions and services provided by unionoids is of global interest (Lopes-Lima et al. 2017) and has been formalized in international and national legal frameworks such as the Habitats Directive (Council of the European Communities 1992) and the European Water Framework Directive (Council of the European Communities 2000). However, implementing such legislation in terms of conservation action still needs basic knowledge of species-specific ecology (e.g., reproduction timing and critical population sizes), and host-fish interactions (e.g., host-fish species and availability) for many unionoid species. This lack of knowledge is problematic as it restricts accurate prioritization in trade-offs between freshwater biodiversity and social needs, such 
as bridge and hydropower infrastructure construction. This complexity is furthered by different costs and benefits involved with restoring mussel populations of different sizes, making conservation prioritization in a varying environment difficult (Geist 2015; Smith et al. 2015).

To facilitate prioritization in management trade-offs, we performed a field study on the thick-shelled river mussel, Unio crassus, one of Europe's most threatened unionoids. This species is a stream-dwelling mussel, for which, to our knowledge, a host fish attraction strategy has only been observed in the southern part of its range (e.g. Vicentini 2005); such a strategy was not observed during the present study. We evaluated how mussel density and density of two of its primary host fish species affect mussel reproduction potential. To do this we followed the reproduction season of $U$. crassus at three sites in a population in the river Tommarpsån, southern Sweden. We assumed that in a dense mussel bed with many potentially reproducing adults, the proportion of gravid mussels would be higher than in a low-density mussel bed with fewer adults. We predicted that this would result in higher glochidia encapsulation rates on the primary host fish species naturally occurring in the river (European bullhead, Cottus gobio, and common minnow, Phoxinus phoxinus), for which we investigated glochidia prevalence and fish abundance over the mussel reproduction season. Combining 'glochidia encapsulation rates on fish' and 'fish density' renders 'glochidia density' a proxy for the potential number of recruits per area of river. We expected the glochidia density to be highest at high mussel density as a result of beneficial conditions for life-cycle completion regarding juvenile transformation.

\section{Materials and methods}

\section{Study area}

The study was conducted in the River Tommarpsån, located in the region of Skåne in south-

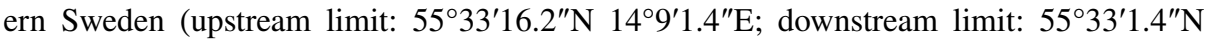
$14^{\circ} 8^{\prime} 27.9^{\prime \prime} \mathrm{E}$ ). The river (total length: $41.9 \mathrm{~km}$, mean flow \pm SD: $0.7 \pm 0.6 \mathrm{~m}^{3} / \mathrm{s}$ ) has a moderate ecological status (classified according to the EU water framework direction, Council of the European Communities 2000), is mainly surrounded by arable land and empties into the Baltic Sea (Stenberg et al. 2012; Water Information System Sweden 2014). The river supports a self-recruiting $U$. crassus population in its middle to lower reaches. Three study sites, referred as to S1 (upstream), S2 (between) and S3 (downstream), all inhabited by $U$. crassus and situated 200-500 m apart from each other, were randomly chosen on a river stretch of about $800 \mathrm{~m}$ length. Although the distance between sites seems small, it is considered sufficient to evaluate small-scale effects of fish and mussel density on the reproductive potential of $U$. crassus. From these sites, P. phoxinus and $C$. gobio had been identified as primary host fish for U. crassus in a previous study (Schneider 2017), in which DNA analyses of glochidia encapsulated on fish gills and transformed juveniles identified $U$. crassus as the sole unionoid in the system. All three study sites are similar in their physical and chemical characteristics (Table 1).

\section{Mussel investigations}

Unio crassus has been described as a short-term breeder, reproducing during spring and early summer (Bauer 2001c). To investigate the proportions of gravid mussels during the 


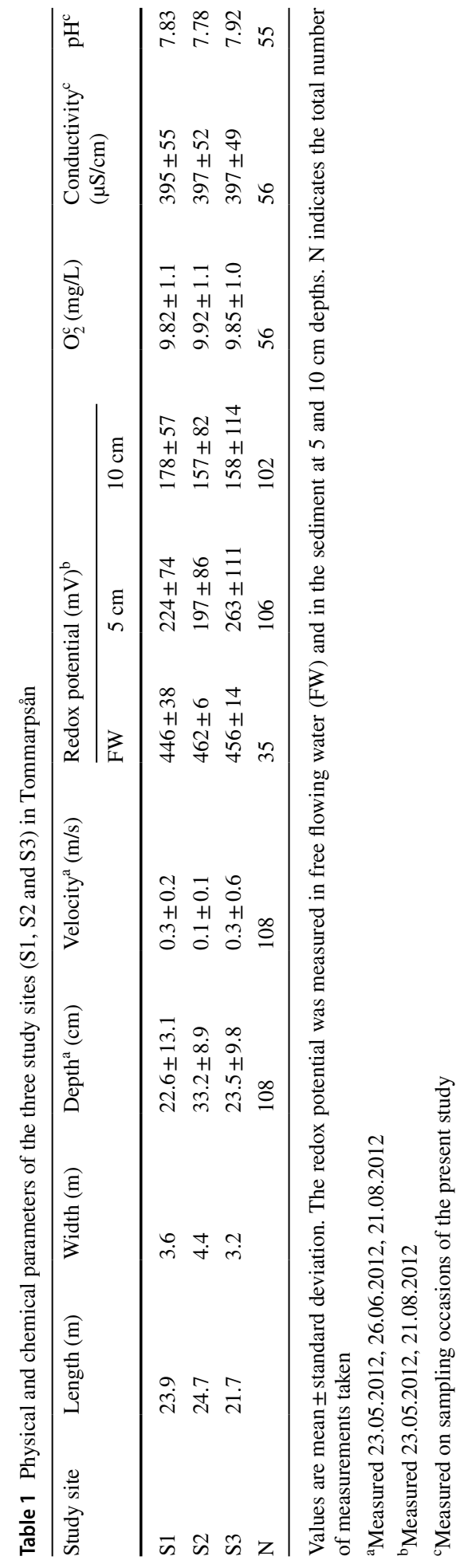


annual reproduction season of $U$. crassus in Sweden, two investigations of mussel gravidity were conducted on 16 and 30 mussels on 18 and 26 April 2013, respectively (the dates correspond to weeks 16 and 17 of the year 2013). Thereafter, approximately 60 individuals at each study site on each occasion were investigated weekly until 23 July 2013, when no mussels were found gravid, resulting in 2176 individual mussel examinations. Mussels visible by their apertures or lying on top of the sediment, as viewed through glass-bottomed viewing buckets, were sampled by hand. The mussels were transferred to $20 \mathrm{~L}$ buckets filled with stream water and fitted with an oxygen supply, and their gravidity status (yes/no) was recorded before they were returned to their original habitats. Mussels were carefully opened with reversing pliers, and gravidity evaluated by visual inspection of marsupial gills (Österling et al. 2008). A mussel with swollen marsupial gills, was assumed gravid (Bednarczuk 1986). A mussel with flat and transparent gills was categorized as non-gravid, including male individuals. The individual shell length (nearest mm, Helama et al. 2017) was noted. The ratio of gravid/non-gravid mussels was calculated for every sampling occasion. Repeated counting (2x) of all mussels visible (siphons and/or shell) at the sediment surface at each study site was conducted to estimate mussel densities. We excluded mussels buried in the sediment as we were interested in the number of mussels taking part in reproduction by being able to disperse sperm and glochidia to the free-flowing water (Pfeiffer and Nagel 2010).

\section{Fish investigations}

Quantitative electrofishing (LUGAB L-600, flat DC, Bohlin et al. 1989) was conducted with two or three successive removals of fish at each study site every second week, starting on 16 May 2013 (corresponding to weeks 20, 22, 24, 26 and 28), always 2 days after a mussel gravidity survey. Fish were identified to species and counted on each fish removal to enable population density estimates.

On every fishing occasion at each study site, subsamples of 10 individuals of $P$. phoxinus and C. gobio were sacrificed (Benzocaine, $>200 \mathrm{mg} / \mathrm{L}$ ), measured for total length (nearest $\mathrm{mm}$ ) and weight (nearest $0.1 \mathrm{~g}$ ), and preserved in $95 \%$ ethanol. The remaining fish were returned to the river after the repeated fish removal at a study site. In a laboratory, the subsamples, representing about $8-9 \%$ of the total catch of C. gobio and P. phoxinus, were thoroughly examined for glochidia infestation using binocular microscopes. Natural glochidia encapsulation rates were estimated through gill dissection and counting of all glochidia attached to one gill side with extrapolation of this number to the total gill (glochidia fish ${ }^{-1}$ ). Schneider (2017) showed that $U$. crassus encapsulation on fish is evenly distributed between the right and left gills. Fish skin and fins were not examined for glochidia infestation, as $U$. crassus glochidia drop off these body parts prior to successful metamorphosis (Engel and Wächtler 1989; Taeubert et al. 2012). The number of glochidia per fish was then multiplied by the species-specific fish density (individuals $\mathrm{m}^{-2}$ ) to calculate the 'glochidia density' (glochidia $\mathrm{m}^{-2}$ ), representing the number of glochidia potentially transforming to juvenile mussels (Österling et al. 2008). In a previous study, Schneider et al. (2017) showed that glochidia encapsulation rates on $P$. phoxinus and C. gobio correspond to transformation rates of $U$. crassus from the fish. Although we assume that transformation rates of juvenile mussels are fish species-dependent due to differences in morphology, behaviour and ecology of the fish species, in the present study, we use glochidia density to estimate the reproductive potential of the mussel. We do so as glochidia density reflects the river-specific ecological importance of a host fish species. 


\section{Water temperature}

Water temperature $\left({ }^{\circ} \mathrm{C}\right)$ was measured hourly by data loggers at each study site. Average temperatures ( \pm standard deviation) were calculated for each week between 18 April and 23 July, which corresponds to weeks 16-30 of the year 2013.

\section{Statistical analyses}

All statistical analyses were carried out according to simple repeated measures ANOVA in a randomized block design (Quinn and Keough 2002), including 'week' as a random blocking factor, and comparing among 'study sites' (S1, S2, S3) as a fixed factor. The 'proportions of gravid mussels' and 'mussel length' were compared among 'study sites' in separate ANOVAs for 'week' 18-28. 'Glochidia infestation', 'fish density' and 'glochidia density' were compared among 'study sites' and between 'fish species' ( $P$. phoxinus or C. gobio, fixed factor) in separate two-way ANOVAs including the 'study sites' $\times$ ' fish species' interaction term along with blocking factor 'week' (20-28). Significances were accepted at $\alpha \leq 0.05$, normality of residuals was confirmed using Kolmogorov-Smirnov tests ( $p>0.2$ for all dependent variables), and post hoc Tukey HSD tests were carried out for factor 'study sites'. All statistical analyses were performed in IBM SPSS statistics version 22.0.0.2.

\section{Results}

\section{Mussel investigations}

Gravid mussels were found between mid-April and the beginning of July (weeks 17-27), when average stream temperatures were between $8.8 \pm 1.3{ }^{\circ} \mathrm{C}$ and $17.8 \pm 1.1{ }^{\circ} \mathrm{C}$ (Fig. 1). The reproductive season of $U$. crassus was completed by week 27 , as mussels examined in

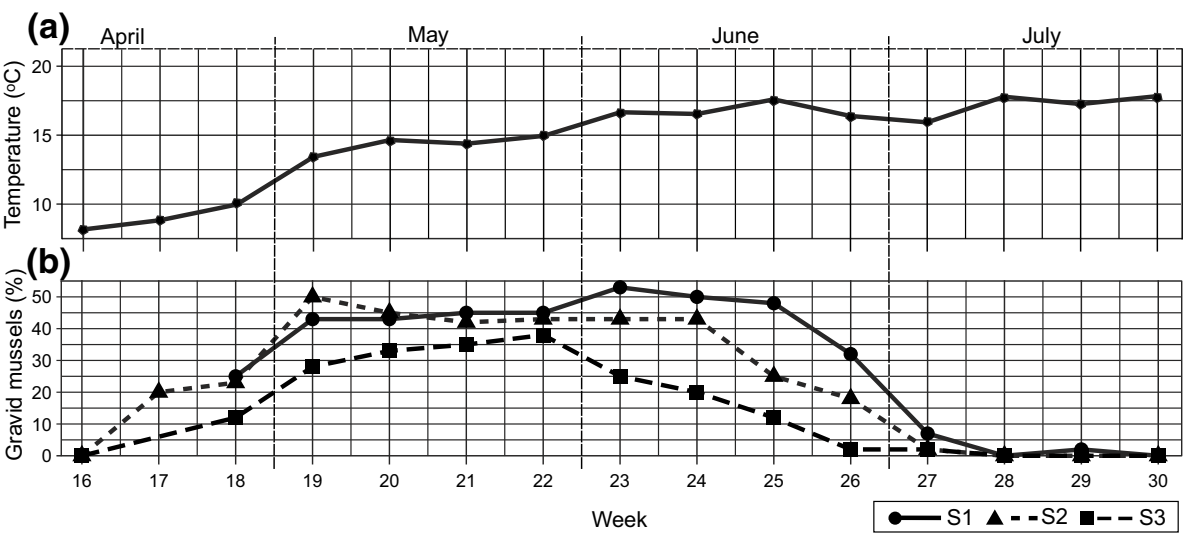

Fig. 1 a Average water temperature $\left({ }^{\circ} \mathbf{C}\right)$ in the River Tommarpsån, and b percentage of gravid mussels $(\%)$ at the study sites S1, S2 and S3 during week 16-30 (temperature at S2 between weeks 21-28 only) in 2013. Lines between means and percentages are added for clarity 
weeks 28,29 and $30(n=544)$ were not gravid, except for one individual carrying a partial brood. On average, $31 \%$ of the mussels investigated were gravid (all study sites, weeks 17-27). The maximum proportions of mussels carrying broods were 58\%, 50\% and $38 \%$ for S1, S2 and S3, respectively (in weeks 23, 19 and 22, respectively). There was a significant difference among study sites in proportions of gravid mussels $\left(\mathrm{F}_{2,20}=17.51, \mathrm{p}<0.001\right.$, Fig. 1b). A Tukey HSD test revealed that $S 1$ had significantly higher proportions of gravid mussels than S2 $(\mathrm{p}<0.01)$ and S3 $(\mathrm{p}<0.001)$, and that S2 had higher proportions of gravid mussels than S3 $(\mathrm{p}<0.01)$.

Mussel density was considered as 'low' (0.9 individuals $\left.\mathrm{m}^{-2}\right)$, 'high' (14.8 individuals $\mathrm{m}^{-2}$ ), and 'low/intermediate' (2.3 individuals $\mathrm{m}^{-2}$ ) at study sites $\mathrm{S} 1, \mathrm{~S} 2$ and $\mathrm{S} 3$, respectively. The largest gravid mussel had a $96 \mathrm{~mm}$ long shell, and the largest non-gravid mussel was $98 \mathrm{~mm}$ long. The mussels at S3 $(65 \pm 7 \mathrm{~mm})$ were significantly smaller than mussels at $\mathrm{S} 1(70 \pm 7 \mathrm{~mm})$ and $\mathrm{S} 2\left(69 \pm 6 \mathrm{~mm} ; \mathrm{F}_{2,1761}=126.595, \mathrm{p}<0.001\right.$; Tukey HSD: $\left.\mathrm{p}<0.001\right)$.

\section{Fish density}

Cottus gobio and $P$. phoxinus were the most abundant fish species caught during weeks 18-28. These species represented 99\% of the 3675 fish specimens caught (C. gobio: $52 \%$; P. phoxinus: 47\%). Salmo trutta, Esox lucius and Lampetra planeri accounted for the remaining one percent. Due to low abundances of these fish species and because $C$. gobio and $P$. phoxinus are the primary host-fish for U. crassus in Tommarpsån, the following results focus only on $C$. gobio and $P$. phoxinus. The average densities of both species (individuals $100 \mathrm{~m}^{-2}$ ) were $162.2 \pm 158.6($ mean $\pm \mathrm{SD}), 120.0 \pm 51.1$, and $289.9 \pm 205.7$ at $\mathrm{S} 1$, S2 and S3, respectively. The ANOVA showed a significant main effect of 'study site' on 'fish density' $\left(\mathrm{F}_{2,19}=5.12, \mathrm{p}=0.02\right)$, resulting from $\mathrm{S} 3$ having higher fish densities than S2 (Tukey HSD test: S3-S2, p=0.03; S3-S1, p=0.10; S2-S1, p=0.76). However, the ANOVA showed no significant main effect of 'fish species' $\left(\mathrm{F}_{1,19}=0.53, \mathrm{p}=0.46\right)$, nor a 'study sites' $X$ 'fish species' interaction effect $\left(\mathrm{F}_{2,19}=0.68, \mathrm{p}=0.52\right)$ on 'fish density'. Still, $\mathrm{S} 1$ and S3 had high densities of $P$. phoxinus early in the study period, and these densities decreased over the study period. S2 had low densities of $P$. phoxinus throughout, and no $P$. phoxinus were caught in S2 in week 28. Cottus gobio had a somewhat different density profile over the study period, with less pronounced early high densities and less of a decrease over time. After week 24, C. gobio densities were generally higher than those of $P$. phoxinus. As densities of the relatively stationary $C$. gobio did not decrease over time as did $P$. phoxinus we do not consider an effect of our standardized sampling on fish densities.

\section{Glochidia encapsulation rates}

Gill examination of $C$. gobio $(\mathrm{n}=150)$ and $P$. phoxinus $(\mathrm{n}=140)$ resulted in an overall average glochidia encapsulation rate of $6.6 \pm 9.8$ glochidia per fish individual (glochidia fish $^{-1}$ ) with high variation among individuals. Glochidia occurred in about $63 \%$ of fish gills examined, following the seasonal pattern of mussel gravidity with 1-2 weeks delay. The lowest encapsulation rates occurred at the beginning and the end of the study period. High infestations with up to 66 glochidia per fish occurred around week 22, when stream temperatures were about $15{ }^{\circ} \mathrm{C}$. Average glochidia encapsulation rates were significantly

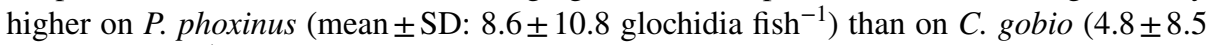
glochidia fish $\left.{ }^{-1} ; \mathrm{F}_{1,19}=11.539, \mathrm{p}<0.01\right)$, and significantly higher at S3 $(9.7 \pm 11.9$ glochidia fish $\left.{ }^{-1}\right)$ than at S1 $\left(3.8 \pm 5.6\right.$ glochidia fish $\left.{ }^{-1}\right)$ and S2 $\left(6.4 \pm 10.7\right.$ glochidia fish $\left.^{-1}\right)$ 
$\left(\mathrm{F}_{2,19}=12.53, \mathrm{p}<0.001\right.$, Tukey HSD test: S3-S1, $\mathrm{p}<0.001 ; \mathrm{S} 3-\mathrm{S} 2, \mathrm{p}=0.04 ; \mathrm{S} 2-\mathrm{S} 1$, $\mathrm{p}=0.1$, Fig. 2b) without any significant interaction between 'study site' and 'fish species' $\left(\mathrm{F}_{2,19}=2.51, \mathrm{p}=0.11\right)$.

\section{Glochidia density per area of stream}

Glochidia density, calculated as 'glochidia encapsulation rate' times 'fish density', differed significantly between study sites $\left(\mathrm{F}_{2,19}=9.85, \mathrm{p}<0.01\right)$. At $\mathrm{S} 3$ the glochidia density $\left(\right.$ mean \pm SD $24.9 \pm 38.5$ glochidia $\mathrm{m}^{-2}$ ) was significantly higher than at $\mathrm{S} 1(6.2 \pm 15.0$ glochidia $\left.\mathrm{m}^{-2}\right)$ and $\mathrm{S} 2\left(7.2 \pm 11.8\right.$ glochidia $\mathrm{m}^{-2}$ ) (TukeyHSD test: $\mathrm{S} 3-\mathrm{S} 1, \mathrm{p}<0.01$; $\mathrm{S} 3-\mathrm{S} 2, \mathrm{p}<0.01 ; \mathrm{S} 2-\mathrm{S} 1, \mathrm{p}=0.99$, Fig. $2 \mathrm{c})$. The pattern of glochidia density was thus similar between $P$. phoxinus $\left(14.1 \pm 24.6\right.$ glochidia $\left.\mathrm{m}^{-2}\right)$ and $C$. gobio $(11.9 \pm 28.3$ glochidia $\mathrm{m}^{-2}$ ) during weeks 20-28 (Fig. 2c) since there were no significant effects of factor 'fish species' $\left(\mathrm{F}_{1,19}=0.03, \mathrm{p}=0.86\right)$ or 'study site' $\times$ 'fish species' interaction $\left(\mathrm{F}_{2,19}=0.95\right.$, $\mathrm{p}=0.40$ ) on 'glochidia density'.

\section{Discussion}

In this study, the reproductive potential of $U$. crassus differed among localities with different densities of non-buried mussels. However, contradicting our assumptions, higher glochidia density (a proxy for the potential number of recruits per area of river) occurred at the site with 'low/intermediate' mussel density than at the sites with 'high' and 'low' densities. This suggests that relatively low mussel densities, possibly above a critical population density threshold, can have a comparably high reproduction potential as a result of multiplicative effects of ample host fish availability and elevated

(a)

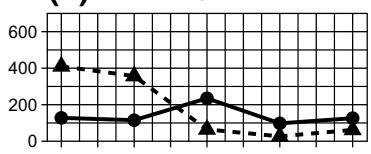

S2

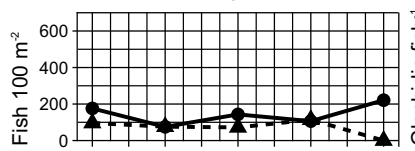

S3

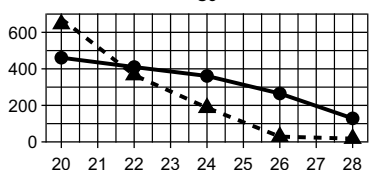

(b)

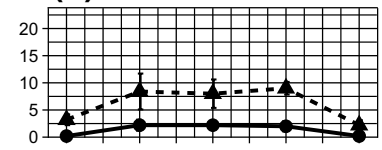

S2

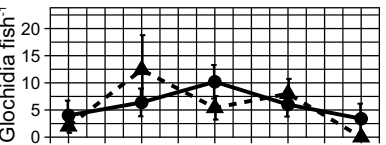

S3

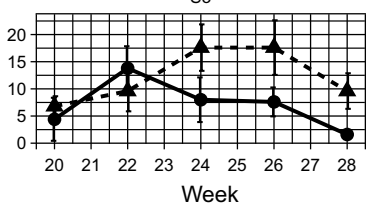

(c)

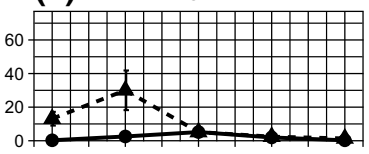

S2

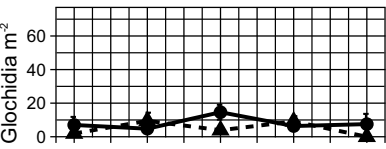

S3

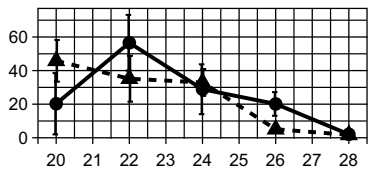

Fig. 2 a Total fish density (fish $100 \mathrm{~m}^{-2}$ ), b average encapsulation rates of glochidia per fish individual (glochidia fish ${ }^{-1}$ ), and $\mathbf{c}$ average glochidia density $\left(\right.$ glochidia $\mathrm{m}^{-2}$ ) on Cottus gobio $(\mathrm{n}=150)$ and Phoxinus phoxinus $(\mathrm{n}=140)$ from study sites S1, S2 and S3 during weeks 20-28 in 2013. Error bars denote the standard error of the mean. Lines between means are added for clarity 
glochidia encapsulation rates on fish. However, encapsulation rates of glochidia did not correlate with local proportions of gravid mussels, indicating that the proportion of mussels taking part in reproduction does not necessarily increase the glochidia prevalence on fish, whereas both host fish density and species do. This is supported by our findings of (1) different host fish densities among the study sites, (2) significantly higher natural glochidia encapsulation rates on P. phoxinus than on C. gobio, and (3) similarly higher densities of $C$. gobio towards the end of the study period, prolonging host availability for $U$. crassus after $P$. phoxinus leave their spawning grounds. Our results therefore show that prioritization in conservation management trade-offs, such as choice of habitats that should be preserved or not, may be better based on considerations of such multiplicative effects on the reproduction potential of mussels and not on mussel densities and proportions of gravid mussels alone.

\section{Density effects on mussel reproduction}

Mussel reproduction took place between mid-April and the beginning of July, probably driven by temperature (Hastie and Young 2003), as temperature affects metabolic processes in mussels (Hochwald 1997) and adaptations in the mussel-host interaction (Barnhart et al. 2008; Schneider et al. 2018). The proportions of gravid mussels were significantly higher at the site with low mussel density than the sites with higher mussel densities, contradicting our assumption and the findings of McLain and Ross (2005) and Österling (2015), who reported higher proportions of gravid mussels in high-density mussel beds of other mussel species. The ratio of gravid to non-gravid mussels also temporarily exceeded $50 \%$, in spite of $U$. crassus usually having a sex ratio of 1:1 (Hochwald and Bauer 1990) and rarely being hermaphrodites (Pekkarinen 1993), indicating high female reproductive activity. Whether hermaphroditism occurs in Tommarpsån has yet to be investigated.

Allee effects in the form of reduced reproduction below critical mussel densities have been suggested for $U$. crassus (Bauer and Wächtler 2001; Hochwald and Bauer 1990; Watters 2001). Allee effects may arise due to sperm limitation at low mussel densities, particularly when rivers have impeded flow velocity (Downing et al. 1993; Terui et al. 2015). This is unlikely to be the case for $U$. crassus in the River Tommarpsån, which has a moderate and steady flow during late spring and summer, and mussels distributed relatively evenly along the river stretch investigated in the present study enhancing sperm distribution and availability (Ferguson et al. 2013; Mosley et al. 2014). Therefore, the frequency of egg fertilization, and thereby the numbers of glochidia released to the free-flowing water should not vary among our study sites. We suggest this because the mussel bed with the lowest mussel density supported the highest proportion of gravid mussels. Also, the level of glochidia infestation on fish did not depend on the size of the mussel individuals at a study site, as no difference in glochidia encapsulation rates was detected between the mussel beds with larger and significantly smaller (shorter shell) mussels, a finding that corroborates Hochwald (1997) and suggests that fertility of $U$. crassus is independent of mussel size or age. However, estimates of the reproductive potential of $U$. crassus should consider, for example, demographic processes with low effective population sizes (Haag 2012; Nunney and Campbell 1993), and, according to our studies, be evaluated in the light of biological interactions and life-history traits of both mussels and fish hosts. 


\section{Multiplicative effects on mussel reproduction potential}

Even if reduced host fish availability can impede mussel recruitment (Arvidsson et al. 2012; Haag and Stoeckel 2015; Stoeckl et al. 2015), this does not seem to be the case for $U$. crassus in the present study. First, average fish densities of $P$. phoxinus and $C$. gobio were about nine times higher than the average fish densities of primary hosts ( $P$. phoxinus and $S$. cephalus) reported for streams with functional U. crassus recruitment (Stoeckl et al. 2015). Second, the highest 'glochidia density' was found at 'low/intermediate' mussel density as a result of high host fish densities and glochidia encapsulation rates on fish. This suggests a high reproduction potential at relatively low mussel densities, and also hints at mechanisms behind infestation rates beyond those of mussel and host fish densities alone.

Behavioural and life history traits of host fish have been considered critical for glochidia infestation, with the swimming, spawning and feeding behaviour of fish greatly affecting the level of infestation (Jansen et al. 2001). Phoxinus phoxinus is a shoaling fish species that spawns in specific habitats during May-July (Frost 1943). Our study suggests that aggregation of $P$. phoxinus and its high swimming activity during spawning increase glochidia prevalence and result in high glochidia densities, as found at the 'low/intermediate' mussel bed. This result is similar to that of Wengström et al. (2016), which demonstrated a positive relationship between the swimming speed of brown trout (affecting fish ventilation rates) and the level of infestation with glochidia of the freshwater pearl mussel (Margaritifera margaritifera). Hence, the spawning behaviour of $P$. phoxinus may have a major influence on the mussel reproduction potential, rendering this fish species an important host for U. crassus.

Throughout the $U$. crassus reproductive period, C. gobio carried significantly lower numbers of glochidia per fish individual compared to $P$. phoxinus, despite this benthic fish species spawning synchronously with $U$. crassus, when it also abandons its solitary life sheltering under stones (Mills and Mann 1983), thereby increasing the chance for glochidia exposure. However, besides differences in swimming behaviour, the higher glochidia prevalence on $P$. phoxinus may hint at a generally higher host suitability of this cyprinid. Further research is needed to elucidate host suitability differences, including aspects of both fish behaviour and physiology, and juvenile mussel transformation success (Levine et al. 2012; Schneider et al. 2018; Taeubert et al. 2012).

Juvenile transformation success is a critical stage for mussel recruitment. In the present study, the reproduction potential of $U$. crassus was evaluated as 'glochidia density' and not juvenile transformation. As introduced in the methods section, this procedure is justified by a very high juvenile transformation success from glochidia that have been encapsulated for a critical period of three days in artificial infestations with mussels and fish from the study river Tommarpsån (Schneider et al. 2017). In those experiments, no glochidia loss was found on $C$. gobio and $P$. phoxinus after that critical period, suggesting that both species are highly suitable hosts for $U$. crassus. Moreover, the current study included repeated fishing during the mussel reproduction season during which the probability of glochidia attachment to fish 3 days prior to fishing is high. We therefore suggest that reproduction potential can be proxied by glochidia examination on gills of naturally infested fish.

The glochidia densities did not differ between $C$. gobio and $P$. phoxinus. The lower glochidia infestation rates on $C$. gobio were most likely compensated by the comparably higher densities of $C$. gobio towards the end of the $U$. crassus reproduction season. Similar glochidia densities suggest similar host functions between fish species; and the possibility for $U$. crassus to recruit similarly well on different hosts implies ecological resilience of $U$. 
crassus recruitment. The option of alternative hosts among time periods and microhabitats could ensure successful reproduction, especially with recurrent disturbances that vary temporally and spatially and affect fish species differently (Pandolfo et al. 2012).

\section{Conclusions}

Conservation of unionid mussels as keystone species in freshwaters is essential to prevent further extinctions and to maintain the ecosystem functions and services that these highly imperilled molluscs provide (Lopes-Lima et al. 2017). The present study shows that management trade-offs and prioritization should not be based on information of mussel abundance and host fish density alone, such that high biodiversity value is generally assumed for large and dense populations. Instead, knowledge gained from studies on local mussel beds and multiplicative effects of host availability, host species composition and infestation, should be taken into consideration. Our conclusions are based on evaluation of one population, which prompts the need for future studies of multiple populations and habitats. Such studies may reveal high reproduction potential in low-density mussel beds, which, according to our results, can be linked to species-specific behavioural and life history traits of host fish. Host characteristics may moreover work in concert with factors such as habitat quality, post-parasitic juvenile survival and genetic variation, in accounting for recruitment potential of unionoids, as suggested by other studies (e.g. Berg et al. 2008; Denic et al. 2014; Geist 2010; Neves and Widlak 1987). Local knowledge of such effects should prove pivotal for management prioritization and trade-offs between values, contributing to adaptive conservation strategies, cost-efficient management, and ultimately the preservation of high ecosystem function and service.

Acknowledgements We thank K. Wutz and S. Nordquist for assisting with field and laboratory work. This study was facilitated by I. Olsson, project manager of the European LIFE project 'UnioCrassusforLIFE' (LIFE10 NAT/SE/000046) and the funding by the European Commission and FORTUM (Nordic Environmental Fund).

\section{Compliance with ethical standards}

Conflict of interest The authors declare that they have no conflict of interest.

Open Access This article is distributed under the terms of the Creative Commons Attribution 4.0 International License (http://creativecommons.org/licenses/by/4.0/), which permits unrestricted use, distribution, and reproduction in any medium, provided you give appropriate credit to the original author(s) and the source, provide a link to the Creative Commons license, and indicate if changes were made.

\section{References}

Aldridge DC, Fayle TM, Jackson N (2007) Freshwater mussel abundance predicts biodiversity in UK lowland rivers. Aquat Conserv 17:554-564. https://doi.org/10.1002/aqc.815

Arvidsson BL, Karlsson J, Österling ME (2012) Recruitment of the threatened mussel Margaritifera margaritifera in relation to mussel population size, mussel density and host density. Aquat Conserv 22:526532. https://doi.org/10.1002/aqc.2240 
Barnhart MC, Haag WR, Roston WN, Barnhart MC, Haag WR, Roston WN (2008) Adaptations to host infection and larval parasitism in Unionoida. J North Am Benthol Soc 27:370-394. https://doi. org/10.1899/07-093.1

Bauer G (2001a) Characterization of Unionoida (=Naiads). In: Bauer G, Wächtler K (eds) Ecology and evolution of the freshwater mussels unionoida. Springer-Verlag, Berlin, pp 3-4

Bauer G (2001b) Life-history variation on different taxonomic levels of najads. In: Bauer G, Wächtler K (eds) Ecology and evolution of the freshwater mussels unionoida. Springer-Verlag, Berlin, pp 83-91

Bauer G (2001c) Framework and driving forces for the evolution of naiad life histories. In: Bauer G, Wächtler K (eds) Ecology and evolution of the freshwater mussels unionoida. Springer-Verlag, Berlin, pp 233-255

Bauer G, Wächtler K (2001) Environmental relationships of naiads: threats, impact on the ecosystem, indicator function. In: Bauer G, Wächtler K (eds) Ecology and evolution of the freshwater mussels unionoida. Springer-Verlag, Berlin, pp 311-315

Bednarczuk J (1986) Untersuchungen zu Wirtsfischspektrum und Entwicklung der Bachmuschel Unio crassus. Dissertation, Tierärtzliche Hochschule Hanover

Berg DJ, Levine TD, Stoeckel JA, Lang BK (2008) A conceptual model linking demography and population genetics of freshwater mussels. J North Am Benthol Soc 27:395-408. https://doi. org/10.1899/07-091.1

Bohlin T, Hamrin S, Heggberget TG, Rasmussen G, Saltveit SJ (1989) Electrofishing-Theory and practice with special emphasis on salmonids. Hydrobiologia 173:9-43. https://doi.org/10.1007/BF000 08596

Cardinale BJ, Duffy JE, Gonzalez A, Hooper DU, Perrings C, Venail P, Narwani A, Mace GM, Tilman D, Wardle DA, Kinzig AP, Daily GC, Loreau M, Grace JB, Larigauderie A, Srivastava DS, Naeem S (2012) Biodiversity loss and its impact on humanity. Nature 486:59-67. https://doi.org/10.1038/ nature 11148

Collier KJ, Probert PK, Jeffries M (2016) Conservation of aquatic invertebrates: concerns, challenges and conundrums. Aquat Conserv 26:817-837. https://doi.org/10.1002/aqc.2710

Council of the European Communities (1992) Directive 92/43/EEC of the European Parliament and the Council of 21 May 1992 on the conservation of natural habitats and of wild fauna and flora. OJEU L 206:7-50

Council of the European Communities (2000) Directive 2000/60/EC of the European Parliament and the Council of 23rd October 2000 establishing a framework for community action in the field of water policy. OJEU L 327:1-72

Cuttelod A, Seddon MB, Neubert E (2011) European red list of non-marine molluscs. IUCN red list of threatened species. Regional assessments. Publications Office of the European Union, Luxembourg

Denic M, Stoeckl K, Gum B, Geist J (2014) Physicochemical assessment of Unio crassus habitat quality in a small upland stream and implications for conservation. Hydrobiologia 735:111-122. https:// doi.org/10.1007/s10750-013-1467-z

Downing JA, Rochon Y, Pérusse M, Harvey H (1993) Spatial Aggregation, Body Size, and Reproductive Success in the Freshwater Mussel Elliptio complanata. J North Am Benthol Soc 12:148-156. https ://doi.org/10.2307/1467344

Dudgeon D, Arthington AH, Gessner MO, Kawabata Z-I, Knowler DJ, Lévêque C, Naiman RJ, Prieur-Richard A-H, Soto D, Stiassny MLJ, Sullivan CA (2006) Freshwater biodiversity: importance, threats, status and conservation challenges. Biol Rev 81:163-182. https://doi.org/10.1017/S1464793105006950

Engel H, Wächtler K (1989) Some peculiarities in developmental biology of two forms of the freshwater bivalve Unio crassus in northern Germany. Arch Hydrobiol 115:441-450

Ferguson CD, Blum MJ, Raymer ML, Eackles MS, Krane DE (2013) Population structure, multiple paternity, and long-distance transport of spermatozoa in the freshwater mussel Lampsilis cardium (Bivalvia: Unionidae). Freshw Sci 32:267-282. https://doi.org/10.1899/12-028.1

Frost WE (1943) The natural history of the minnow, Phoxinus phoxinus. J Anim Ecol 12:139-162

Geist J (2010) Strategies for the conservation of endangered freshwater pearl mussels (Margaritifera margaritifera L.): a synthesis of conservation genetics and ecology. Hydrobiologia 644:69-88. https://doi.org/10.1007/s10750-010-0190-2

Geist J (2011) Integrative freshwater ecology and biodiversity conservation. Ecol Indic 11:1507-1516. https://doi.org/10.1016/j.ecolind.2011.04.002

Geist J (2015) Seven steps towards improving freshwater conservation. Aquat Conserv 25:447-453. https://doi.org/10.1002/aqc.2576

Haag WR (2012) North American freshwater mussels: natural history, ecology, and conservation. Cambridge University Press, Cambridge 
Haag WR, Stoeckel JA (2015) The role of host abundance in regulating populations of freshwater mussels with parasitic larvae. Oecologia 178:1159-1168. https://doi.org/10.1007/s00442-015-3310-X

Hastie LC, Young MR (2003) Timing of spawning and glochidial release in Scottish freshwater pearl mussel (Margaritifera margaritifera) populations. Freshw Biol 48:2107-2117. https://doi.org/10.10 46/j.1365-2427.2003.01153.x

Helama S, Valovirta I, Nielsen JK (2017) Growth characteristics of the endangered thick-shelled river mussel (Unio crassus) near the northern limit of its natural range. Aquat Conserv 27:476-491. https://doi.org/10.1002/aqc. 2698

Hochwald S (1997) Das Beziehungsgefüge innerhalb der Größenwachstums- und Fortpflanzungsparameter bayrischer Bachmuschelpopulationen (Unio crassus Phil. 1788) und dessen Abhängigkeit von Umweltparametern. Dissertation, University Bayreuth

Hochwald S, Bauer G (1990) Untersuchungen zur Populationsökologie und Fortpflanzungsbiologie der Bachmuschel Unio crassus (PHIL.) 1788. Schriftenreihe Bayer. Landesamt fuer Umweltschutz 97

Howard JK, Cuffey Kurt M (2006) The functional role of native freshwater mussels in the fluvial benthic environment. Freshw Biol 51:460-474. https://doi.org/10.1111/j.1365-2427.2005.01507.x

IUCN (2018) The IUCN Red list of threatened species: version 2018-1.. Accessed 9 Sept 2018

Jansen W, Bauer G, Zahner-Meike E (2001) Glochidial mortality in freshwater mussels. In: Bauer G, Wächtler K (eds) Ecology and evolution of the freshwater mussels unionoida, vol 145. Springer-Verlag, Berlin, pp 185-211

Kapos V, Manica A, Aveling R, Bubb P, Carey P, Entwistle A, Hopkins J, Mulliken T, Safford R, Stattersfield A, Walpole MJ, Balmford A (2010) Defining and measuring success in conservation. In: LeaderWilliams N, Adams WM, Smith RJ (eds) Trade-offs in conservation: deciding what to save. Wiley Blackwell, Oxford, pp 73-93

Leader-Williams N, Adams WM, Smith RJ (2010) Deciding what to save: trade-offs in conservation. In: Leader-Williams N, Adams WM, Smith RJ (eds) Trade-offs in conservation: deciding what to save. Wiley Blackwell, Oxford, pp 1-13

Levine TD, Lang BK, Berg DJ (2012) Physiological and ecological hosts of Popenaias popeii (Bivalvia: Unionidae): laboratory studies identify more hosts than field studies. Freshw Biol 57:1854-1864. https ://doi.org/10.1111/j.1365-2427.2012.02844.x

Limm MP, Power ME (2011) Effect of the western pearlshell mussel Margaritifera falcata on Pacific lamprey Lampetra tridentata and ecosystem processes. Oikos 120:1076-1082. https://doi.org/10.111 1/j.1600-0706.2010.18903.x

Lopes-Lima M, Sousa R, Geist J, Aldridge DC, Araujo R, Bergengren J, Bespalaya Y, Bódis E, Burlakova L, van Damme D, Douda K, Froufe E, Georgiev D, Gumpinger C, Karatayev A, Kebapçi Ü, Killeen I, Lajtner J, Larsen BM, Lauceri R, Legakis A, Lois S, Lundberg S, Moorkens E, Motte G, Nagel KO, Ondina P, Outeiro A, Paunovic M, Prié V, von Proschwitz T, Riccardi N, Rudzīte M, Rudzītis M, Scheder C, Seddon M, Şereflişan H, Simić V, Sokolova S, Stoeckl K, Taskinen J, Teixeira A, Thielen F, Trichkova T, Varandas S, Vicentini H, Zajac K, Zajac T, Zogaris S (2017) Conservation status of freshwater mussels in Europe: state of the art and future challenges. Biol Rev 92:572-607. https://doi. org/10.1111/brv.12244

Lopes-Lima M, LE Burlakova, Karatayev AY, Mehler K, Seddon M, Sousa R (2018) Conservation of freshwater bivalves at the global scale: diversity, threats and research needs. Hydrobiologia. https://doi. org/10.1007/s10750-017-3486-7

Luck GW, Daily GC, Ehrlich PR (2003) Population diversity and ecosystem services. Trends Ecol Evol 18:331-336. https://doi.org/10.1016/S0169-5347(03)00100-9

Lydeard C, Cowie RH, Ponder WF, Bogan AE, Bouchet P, Clark SA, Cummings KS, Frest TJ, Gargomony O, Herbert DGI, Hershler R, Perez KE, Roth B, Seddon M, Strong EE, Thomson FG (2004) The global decline of nonmarine mollusks. Bioscience 54:321. https://doi.org/10.1641/00063568(2004)054\%5b0321:TGDONM\%5d2.0.CO;2

Mace GM (2010) Drivers of biodiversity change. In: Leader-Williams N, Adams WM, Smith RJ (eds) Trade-offs in conservation: deciding what to save. Wiley Blackwell, Oxford, pp 349-364

McLain DC, Ross MR (2005) Reproduction based on local patch size of Alasmidonta heterodon and dispersal by its darter host in the Mill River, Massachusetts, USA. J North Am Benthol Soc 24:139-147. https://doi.org/10.1899/0887-3593(2005)024\%3c0139:RBOLPS\%3e2.0.CO;2

Mills CA, Mann RHK (1983) The bullhead Cottus gobio, a versatile and successful fish. In: Freshwater Biological Association (ed) Fifty-first annual report for the year ended 31st March 1983. Annual Report, Freshwater Biological Association, Ambleside. Freshwater Biological Association, Ambleside, pp $76-88$

Mosley TL, Haag WR, Stoeckel JA (2014) Egg fertilisation in a freshwater mussel: effects of distance, flow and male density. Freshw Biol 59:2137-2149. https://doi.org/10.1111/fwb.12417 
Myers N, Mittermeier RA, Mittermeier CG, da Fonseca GA, Kent J (2000) Biodiversity hotspots for conservation priorities. Nature 403:853-858. https://doi.org/10.1038/35002501

Neves RJ, Widlak JC (1987) Habitat ecology of juvenile freshwater mussels (Bivalvia: Unionidae) in a headwater stream in Virginia. Am Malacol Bull 5:1-7

Nunney L, Campbell KA (1993) Assessing minimum viable population size: demography meets population genetics. Trends Ecol Evol 8:234-239. https://doi.org/10.1016/0169-5347(93)90197-W

Ormerod SJ (2014) Rebalancing the philosophy of river conservation. Aquat Conserv 24:147-152. https:// doi.org/10.1002/aqc. 2452

Österling EM (2015) Timing, growth and proportion of spawners of the threatened unionoid mussel Margaritifera margaritifera: influence of water temperature, turbidity and mussel density. Aquat Sci 77:1-8. https://doi.org/10.1007/s00027-014-0366-3

Österling EM, Greenberg LA, Arvidsson BL (2008) Relationship of biotic and abiotic factors to recruitment patterns in Margaritifera margaritifera. Biol Conserv 141:1365-1370. https://doi. org/10.1016/j.biocon.2008.03.004

Österling EM, Arvidsson BL, Greenberg LA (2010) Habitat degradation and the decline of the threatened mussel Margaritifera margaritifera: influence of turbidity and sedimentation on the mussel and its host. J Appl Ecol 47:759-768. https://doi.org/10.1111/j.1365-2664.2010.01827.x

Pandolfo TJ, Kwak TJ, Cope WG (2012) Thermal tolerances of freshwater mussels and their host fishes: species interactions in a changing climate. Walkerana 15:69-82

Pekkarinen M (1993) Reproduction and condition of unionoid mussels in the Vantaa River, South Finland. Arch Hydrobiol 127:357-375

Pfeiffer M, Nagel KO (2010) Schauen, tasten, graben - Strategien und Methoden für die Erfassung von Bachmuscheln (Unio crassus). Naturschutz und Landschaftsplanung 42:171-179

Quinn GP, Keough MJ (2002) Experimental design and data analysis for biologists. Cambridge University Press, Cambridge

Rodriguez JP Jr, Beard TD, Bennett EM, Cumming GS, Cork SJ, Agard J, Dobson AP, Peterson GD (2006) Trade-offs across space, time, and ecosystem services. Ecol Soc 11:28

Schneider LD (2017) Conservation ecology of the thick-shelled river mussel Unio crassus: The importance of parasite-host interactions. Dissertation, Karlstad University

Schneider LD, Anders Nilsson P, Höjesjö J, Martin Österling E (2017) Local adaptation studies and conservation: Parasite-host interactions between the endangered freshwater mussel Unio crassus and its host fish. Aquat Conserv 27:1261-1269. https://doi.org/10.1002/aqc.2816

Schneider LD, Nilsson PA, Österling EM (2018) Evaluating temperature- and host-dependent reproduction in the parasitic freshwater mussel Unio crassus. Hydrobiologia 810:283-293. https://doi. org/10.1007/s 10750-017-3217-0

Simberloff D, Abele LG (1982) Refuge design and island biogeographic theory: effects of fragmentation. Am Nat 120:41-50. https://doi.org/10.1086/283968

Smith DR, McRae SE, Augspurger T, Ratcliffe JA, Nichols RB, Eads CB, Savidge T, Bogan AE (2015) Developing a conservation strategy to maximize persistence of an endangered freshwater mussel species while considering management effectiveness and cost. Freshw Sci 34:1324-1339. https:// doi.org/10.1086/683121

Soulé ME (1985) What is conservation biology? Bioscience 35:727-734. https://doi.org/10.2307/13100 54

Stenberg M, Åbjörnsson K, Hertonsson P (2012) Vattenvårdsprogram för Tommarpsåns avrinningsområde-bakgrundsmaterial och åtgärdsförslag. Ekoll $\mathrm{AB}$, Malmö

Stoeckl K, Taeubert J-E, Geist J (2015) Fish species composition and host fish density in streams of the thick-shelled river mussel (Unio crassus) - implications for conservation. Aquat Conserv 25:276287. https://doi.org/10.1002/aqc. 2470

Strayer DL, Hunter DC, Smith LC, Borg CK (1994) Distribution, abundance, and roles of freshwater clams (Bivalvia, Unionidae) in the freshwater tidal Hudson River. Freshw Biol 31:239-248

Strayer DL, Downing JA, Haag WR, King TL, Layzer JB (2004) Changing perspectives on pearly mussels, North America's most imperiled animals. Bioscience 54:429-439. https://doi. org/10.1641/0006-3568(2004)054\%5b0429

Taeubert J-E, Gum B, Geist J (2012) Host-specificity of the endangered thick-shelled river mussel (Unio crassus, Philipsson 1788) and implications for conservation. Aquat Conserv 22:36-46. https://doi. org/10.1002/aqc. 1245

Tedesco PA, Bigorne R, Bogan AE, Giam X, Jézéquel C, Hugueny B (2014) Estimating how many undescribed species have gone extinct. Conserv Biol 28:1360-1370. https://doi.org/10.1111/cobi.12285

Terui A, Miyazaki Y, Yoshioka A, Matsuzaki S-IS (2015) A cryptic Allee effect: spatial contexts mask an existing fitness-density relationship. R Soc Open Sci 2:150034. https://doi.org/10.1098/rsos.150034 
Vaughn CC (2010) Biodiversity losses and ecosystem function in freshwaters: emerging conclusions and research directions. Bioscience 60:25-35. https://doi.org/10.1525/bio.2010.60.1.7

Vaughn CC (2018) Ecosystem services provided by freshwater mussels. Hydrobiologia 810:15-27. https ://doi.org/10.1007/s10750-017-3139-x

Vaughn CC, Hakenkamp CC (2001) The functional role of burrowing bivalves in freshwater ecosystems. Freshw Biol 46:1431-1446

Vaughn CC, Taylor CM (2000) Macroecology of a host-parasite relationship. Ecography 23:11-20. https ://doi.org/10.1111/j.1600-0587.2000.tb00256.x

Vaughn CC, Nichols SJ, Spooner DE (2008) Community and foodweb ecology of freshwater mussels. J North Am Benthol Soc 27:409-423. https://doi.org/10.1899/07-058.1

Vicentini H (2005) Unusual spurting behaviour of the freshwater mussel Unio crassus. J Molluscan Stud 71:409-410. https://doi.org/10.1093/mollus/eyi045

Water Information System Sweden (2014). http://viss.lansstyrelsen.se/. Accessed 14 June 2014

Watters GT (2001) The evolution of the Unionacea in North America, and its implications for the worldwide fauna. In: Bauer G, Wächtler K (eds) Ecology and evolution of the freshwater mussels unionoida. Springer-Verlag, Berlin, pp 281-307

Wengström N, Wahlqvist F, Näslund J, Aldvén D, Závorka L, Österling ME, Höjesjö J, Wright J (2016) Do individual activity patterns of brown trout (Salmo trutta) alter the exposure to parasitic freshwater pearl mussel (Margaritifera margaritifera) larvae? Ethology 122:769-778. https://doi.org/10.1111/ eth. 12524

\section{Affiliations}

\section{Lea D. Schneider ${ }^{1}$ (D) P. Anders Nilsson ${ }^{1,2}$. Johan Höjesjö ${ }^{3}$ E. Martin Österling ${ }^{1}$}

1 Department of Environmental and Life Sciences - Biology, Karlstad University, 65188 Karlstad, Sweden

2 Department of Biology - Aquatic Ecology, Lund University, Ecology Building, 22362 Lund, Sweden

3 Department of Biology and Environmental Sciences, University of Gothenburg, 41390 Gothenburg, Sweden 